RAFAt (ZACHOR $^{1}$

\title{
Ustrój miast stołecznych państw Europy Wschodniej (Białoruś, Ukraina, Mołdawia)
}

\section{Wstęp}

Większość współczesnych państw konstytucyjnie gwarantuje szczególny status prawny swoich stolic. Są to ogólne normy, które odsyłają do ustawodawstwa zwykłego, precyzującego status prawny i ustrój stolicy. Miasta stołeczne z jednej strony posiadają status samorządowych jednostek administracyjno-terytorialnych w ramach istniejącego w skali ogólnopaństwowej modelu samorządu lokalnego, z drugiej strony ich szczególna pozycja wynika z faktu bycia siedzibą głównych organów władzy państwowej oraz obcych przedstawicielstw dyplomatycznych. Podobna sytuacja ma miejsce w przypadku Białorusi, Ukrainy i Mołdawii. W państwach tych proces demokratyzacji i decentralizacji władzy nie ma przebiegu liniowego, zaś z okresami względnej liberalizacji i petryfikacji instytucji samorządu lokalnego przeplatają się okresy centralizacji i ograniczenia samorządności. To częściowo z tego powodu za interesujące należy uznać przyjęte modele ustroju stołecznego Mińska, Kijowa i Kiszyniowa. Zagadnienie to nie było przedmiotem uwagi konstytucjonalistów i politologów zarówno w Polsce, jak i poza nią ${ }^{2}$. W poniższym artykule omówiono treść głównych aktów prawnych regulujących te kwestie. Zastosowano przede wszystkim metody egzegezy aktów prawnych i porównawczą.

Materiałem źródłowym stały się głównie konstytucje, ustawy dotyczące ustroju samorządu terytorialnego, ustawy dotyczące stolic poszczególnych państw oraz ich statuty. Jest to w przypadku Białorusi: konstytucja z 1994 r.

1 Dr hab. prof. nadzw. Rafał Czachor, Uczelnia Jana Wyżykowskiego w Polkowicach.

2 W polskiej literaturze przedmiotu należy odnotować artykuł dotyczący ustroju Moskwy: B. Pietrzko, Ustrój i organizacja samorządu lokalnego Moskwy [w:] Samorząd miejski. Zadania, instytucje, normy, S. Wróbel (red.), Poznań-Chorzów 2008, m.in. $\mathrm{z}$ tego powodu stolica Rosji nie jest przedmiotem niniejszych rozważań. 
ze zm. ${ }^{3}$, ustawa o samorządzie lokalnym ${ }^{4}$, ustawa o statusie stolicy Republiki Białoruś - miasta Mińska ${ }^{5}$ i statut Mińska ${ }^{6}$, w przypadku Ukrainy: konstytucja z 1996 r. ze zm. ${ }^{7}$, ustawa o samorządzie lokalnym Ukrainy ${ }^{8}$, ustawa o stolicy Ukrainy - mieście-bohaterze Kijowie ${ }^{9}$ i statut wspólnoty terytorialnej Kijowa ${ }^{10}$, zaś w przypadku Mołdawii - konstytucja ${ }^{11}$, ustawa o lokalnym zarządzaniu publicznym ${ }^{12}$ oraz ustawa o statusie municypalitetu Kiszyniów ${ }^{13}$. Zakres materialny tych aktów prawnych jest dość zróżnicowany. Poniższy artykuł unaocznia zatem także różne podejścia prawodawców trzech republik postradzieckich w zakresie regulacji ustroju samorządu lokalnego i określania ustroju miast stołecznych.

\section{Specyfika samorządu terytorialnego na Białorusi, Ukrainie i Mołdawii}

Przyjmuje się, że w procesie demokratyzacji i decentralizacji państwa samorząd odgrywa wiodącą rolę. Decentralizacja i dekoncentracja władzy odbywa się poprzez rozłożenie kompetencji na różne podmioty w pionowym układzie struktury terytorialnej państwa, a władzę publiczną sprawują ogniwa różnych szczebli ${ }^{14}$. W procesie tym omawiane państwa Europy Wschodniej - Białoruś, Ukraina i Mołdawia - miały wspólny punkt wyjścia w postaci rozwiązań prawnych przyjętych w czasie późnej pierestrojki. Pierwszym aktem prawnym, który do radzieckiego prawodawstwa wpro-

3 Конституция Республики Беларусь, http://pravo.by/pravovaya-informatsiya/ normativnye-dokumenty/konstitutsiya-respubliki-belarus/ (dostęp: 6.10.2018).

4 Закон Республики Беларусь от 20 февраля 1991 г. №617-ХІІ „О местном управлении и самоуправлении в Республике Беларусь”, http://www.levonevski.net/ pravo/razdelb/text646/index.html (dostęp: 6.10.2018).

5 Закон Республики Беларусь от 12.07.2000 №410-3 „О статусе столицы Республики Беларусь - города Минска”, http://pravo.newsby.org/belarus/zakon1/ z343.htm (dostęp: 6.10.2018), dalej: u.M.

6 Решение Минского городского совета депутатов от 26 июня 2001 г. № 193 „Об утверждении устава города Минска”, http://pravo.levonevsky.org/bazaby/ org384/basic/text0187.htm (dostęp: 28.03.2019), dalej: st.M.

7 Konstytucja Ukrainy, Warszawa 1999.

8 Закон України Про місцеве самоврядування в Україні, https://zakon.rada. gov.ua/laws/show/280/97-\%D0\%B2\%D1\%80 (dostęp: 6.03.2019).

9 Закон України Про столицю України - місто-герой Київ, https://zakon.rada. gov.ua/laws/show/401-14 (dostęp: 6.03.2019), dalej: u.K.

10 Статут територіальної громади міста Києва, https://kmr.gov.ua/uk/content/ statut-terytorialnoyi-gromady-mista-kyyeva (dostęp: 6.03.2019), dalej: st.K.

11 Konstytucja Republiki Mołdawii, Warszawa 2014.

12 Закон Nr. 436 от 28.12.2006 о местном публичном управлении, http://lex. justice.md/document_rus.php?id=0D9577C4:27DF0CCC (20.04.2019), dalej: u.l.z.p.

13 Закон Nr. 136 от 17.07.2016 о статуте муниципия Кишинэу, http://lex. justice.md/ru/366632/ (dostęp: 20.04.2019), dalej: u.m.K.

14 A. Lutrzykowski, Samorzad terytorialny - element ładu ustrojowego w Unii Europejskiej, „Athenaeum. Political Science” 2006, nr 14-15. 
wadził pojęcie samorządu lokalnego, była ustawa z dnia 9 kwietnia $1990 \mathrm{r}$. o ogólnych zasadach miejscowego kierowania i gospodarowania w ZSRR ${ }^{15}$. W kolejnych miesiącach poszczególne republiki związkowe przyjmowały zbliżone do niej ustawy republikańskie, które następnie stały się fundamentem dla samorządów lokalnych już w niepodległych republikach postradzieckich. Ustawy te były niejednokrotnie modyfikowane, zaś zakres i efekty procesu decentralizacji są $\mathrm{w}$ poszczególnych republikach nieco inne. Wskazać jednak można na określone wspólne trudności we wdrażaniu i petryfikacji samorządu lokalnego. Jest to przede wszystkim ogólna słabość samorządu, jego ograniczone kompetencje, brak stabilnych podstaw finansowych dla jego funkcjonowania, a także wyłączenie z podległości lokalnym organom uchwałodawczym organów egzekutywy. Organy wykonawcze są (lub do niedawna były) podległe organom władzy centralnej, co daje postawy do używania swoistej amalgamatycznej konstrukcji: „organy miejscowego kierowania i samorządu lokalnego"16.

W przypadku samorządu lokalnego Białorusi stwierdzić należy, że funkcjonuje on w szczątkowej postaci. Co istotne, Białoruś - w odróżnieniu od Mołdawii i Ukrainy - nie ratyfikowała Europejskiej Karty Samorządu Lokalnego z dnia 15 października 1985 r. ${ }^{17}$ Obecny ustrój samorządu lokalnego jest wynikiem reform dokonanych pod rządami Aleksandra Łukaszenki. Od 1994 r. trwa proces recentralizacji władzy publicznej, którego ważnym etapem była gruntowna nowelizacja ustawy samorządowej z $2000 \mathrm{r}^{18} \mathrm{Na}$ system samorządu lokalnego składają się lokalne rady deputowanych oraz organy terytorialnego samorządu społecznego ( $\mathrm{w}$ tym m.in. rady i komitety osiedlowe, blokowe, uliczne). Trójszczeblowa struktura rad lokalnych zawiera poziom obwodowy ( $6 \mathrm{rad}$ obwodowych oraz rada miasta stołecznego Mińska), bazowy (rady miejskie w miastach znaczenia obwodowego oraz rady rejonowe) oraz pierwotny (rady miejskie, osiedli typu miejskiego, wiejskie). Rady deputowanych określone zostały w ustawie jako państwowe organy przedstawicielskie na obszarze określonej jednostki administracyjno-terytorialnej i podstawowe ogniwo samorządu lokalnego gwarantujące realizację działalności organów terytorialnego samorządu społecznego. Oznaczało to formalne włączenie rad do systemu organów państwowych,

15 Закон СССР от 09.04.1990 „Об общих началах местного самоуправления и местного хозяйства в СССР”, http://zaki.ru/pagesnew.php?id=1687 (dostęp: 6.10.2018).

16 Tak stanowi np. Закон Республики Беларусь от 4 января 2010 г. № 108-3 „О местном управлении и самоуправлении в Республике Беларусь”, http://www. pravo.by/main.aspx?guid=3871\&p0 $=\mathrm{H} 11000108 \& \mathrm{p} 2=\{\mathrm{NRPA}\}$ (dostęp: 6.10.2018).

17 Europejska Karta Samorządu Terytorialnego, sporządzona w Strasburgu dnia 15 października 1985 r., Dz.U. 1994 r. Nr 124, poz. 607 ze zm.

18 Закон Республики Беларусь от 10.01.2000 №362-3 „О внесении изменений и дополнений в Закон Республики Беларусь „О местном управлении и самоуправлении в Республике Беларусь", http://www.levonevski.net/pravo/norm2009/num36/ d36275.html (dostęp: 6.10.2018). 
a więc ograniczenie ich samorządowego wymiaru. Egzekutywę jednostek administracyjno-terytorialnych, realizującą zadania wykonawcze i kierownicze, stanowią komitety wykonawcze. Jednocześnie komitety wykonawcze wszystkich szczebli (obwodowego, rejonowego i gminnego) stanowią element składowy centralnej władzy wykonawczej, reprezentując formalnie interesy społeczności lokalnej ${ }^{19}$.

Proces kształtowania się modelu samorządu lokalnego na Ukrainie miał nieco bardziej chaotyczny i niekonsekwentny przebieg. Od momentu uzyskania niepodległości w 1991 r. do 2014 r. samorząd lokalny był włączany w proces wzmacniania bądź osłabiania władzy prezydenckiej. Podobnie jak w przypadku Białorusi wynikało to z faktu podporządkowania lokalnych organów władzy wykonawczej organom tzw. pionu prezydenckiego.

Przełom w tej materii nastąpił w latach 2014-2015, gdy wdrożono pakiet reform decentralizacyjnych. Składają się nań ustawy: $\mathrm{z}$ dnia 17 czerwca 2014 r. o współpracy jednostek terytorialnych $\left(\right.$ hromad) ${ }^{20}$, z dnia 5 lutego $2015 \mathrm{r}$. o zasadach państwowej polityki regionalnej ${ }^{21}$, z dnia 5 lutego $2015 \mathrm{r}$. o dobrowolnych zjednoczeniach jednostek terytorialnych (hromad) ${ }^{22}$ i z dnia 14 lipca 2015 r. o wyborach lokalnych ${ }^{23}$. Obok konsolidacji rozdrobnionych do tej pory jednostek administracyjno-terytorialnych reforma ma na celu wdrożenie faktycznej samorządności. Dokonuje się to poprzez podporządkowanie ciał egzekutywy lokalnym organom stanowiącym. Dotychczasowe administracje państwowe, organy wykonawcze, stają się elementem samorządu, ich szefowie zaś nie będą wyznaczani przez prezydenta, lecz wybierani w wyborach bezpośrednich. W miejsce administracji państwowych jako terenowi przedstawiciele władz państwowych w rejonach mają funkcjonować prefekci o prerogatywach kontrolnych. W miejscowościach liczących powyżej 50 mieszkańców planuje się wprowadzenie instytucji starosty jako organu pomocniczego ${ }^{24}$.

Naprzemienne okresy decentralizacji i recentralizacji dotyczyły również samorządu lokalnego w Mołdawii. Odziedziczony po epoce radzieckiej model przetrwał do $1997 \mathrm{r}$. W latach 1997-2001 rządzące siły proeuropejskie dokonały wzmocnienia samorządu lokalnego, co zostało anulowane

19 Szerzej: R. Czachor, Transformacja systemu politycznego Białorusi w latach 1988-2001, Polkowice 2016.

20 Закон України Про співробітництво територіальних громад, http://zakon3. rada.gov.ua/laws/show/1508-18 (dostęp: 16.03.2019).

21 Закон України Про засади державної регіональної політики, http://zakon3. rada.gov.ua/laws/show/156-19 (dostęp: 16.03.2019).

22 Закон України Про добровільне об'єднання територіальних громад, http:// zakon3.rada.gov.ua/laws/show/157-19 (dostęp: 16.03.2019).

23 Закон України Про місиеві вибори, http://zakon5.rada.gov.ua/laws/show/ 595-viii (dostęp: 16.03.2019).

24 Szerzej: R. Czachor, Reformy ustroju samorzadu terytorialnego Ukrainy od 1990 do 2016 roku, „Samorząd Terytorialny” 2018, nr 3 (327), s. 58-67. 
przez nowe-stare postkomunistyczne elity władzy w latach 2001-200325. Obecny mołdawski model samorządu lokalnego jest dwustopniowy (gminy i rejony). W odróżnieniu od wspomnianych przypadków Białorusi i Ukrainy (do 2014 r.) organ wykonawczy na obu szczeblach samorządu nie jest włączony w struktury władzy centralnej. Na poziomie gmin ich burmistrzowie są wybierani bezpośrednio i za swoją działalność nie ponoszą odpowiedzialności przed radą gminy, zaś na poziomie rejonu organem wykonawczym jest wybierany przez radę rejonową przewodniczący rejonu. Ponosi on odpowiedzialność polityczną przed radą rejonu i może być przez nią zdymisjonowany (decyzją 2/3 radnych). Głównym problemem samorządu lokalnego w Mołdawii jest jego rozdrobnienie oraz brak centralizacji fiskalnej, co odbija się na finansowej kondycji i możliwości realizacji zadań ustawowych ${ }^{26}$.

\section{Podstawy ustroju m.st. Mińska}

W obowiązującym podziale administracyjno-terytorialnym Mińsk funkcjonuje na równi $\mathrm{z}$ obwodami, tj. jest jednostką najwyższego szczebla. W tym sensie nie posiada zatem szczególnej pozycji i np. podobnie jak w poszczególnych obwodach funkcjonuje w nim pomocnik prezydenta Białorusi. Jego zadania, określone dekretem z dnia 11 stycznia 2001 r., to „zasadnicza inspekcja” i kontrola realizacji polityki państwowej ${ }^{27}$.

Rozdział V konstytucji Białorusi „Miejscowe kierowanie i samorząd” określa pozycję ustrojową i zadania lokalnych rad deputowanych jako organów samorządu lokalnego i przewodniczących komitetów wykonawczych jako organów władzy centralnej (art. 117-124). Regulacje te odnoszą się także do Mińska. Ustawa o statusie stolicy Republiki Białoruś - miasta Mińska z dnia 12 lipca 2000 r. składa się z 16 artykułów w 4 rozdziałach. Stanowi ona, że Mińsk jest oddzielną jednostką administracyjno-terytorialną, administracyjno-politycznym, gospodarczym i kulturowym centrum państwa, siedzibą prezydenta państwa, organów władzy, przedstawicielstw dyplomatycznych, konsulatów i przedstawicielstw organizacji międzynarodowych (art. 1 u.M.). Realizacja zadań miasta stołecznego powinna być finansowana $z$ budżetu państwa, aczkolwiek nie jest to obligatoryjne (art. 14 u.M.). Ustawa przewiduje możliwość ograniczenia wjazdu do stolicy, rejestracji (meldunku) obywateli oraz kontroli drogowej i sanitarno-

25 А. Макухин, Реформа административно-территориального деления и местного самоуправления в Республике Молдова: между институииональной теорией и политической практикой, „Eastern Review” 2017, t. 6.

26 Szerzej: R. Czachor, Ustrój samorządu lokalnego w Republice Mołdawii. Ewolucja i stan obecny, „Środkowoeuropejskie Studia Polityczne” 2019, nr 1, s. 59-72.

27 Указ Президента Республики Беларусь от 11.01.2001 №21 „Об утверждении Положения о помощнике Президента Республики Беларусь”, http://pravo. newsby.org/belarus/ukaz3/uk571.htm (dostęp: 4.05.2019). 
-epidemiologicznej, co uzasadnia się bezpieczeństwem organów władzy oraz przedstawicielstw dyplomatycznych (art. 7 u.M.).

$\mathrm{Na}$ miejską radę deputowanych oraz miejski komitet wykonawczy nakłada się szczególne zadania związane z realizacją przez Mińsk funkcji stołecznych. Jest to w szczególności: a) stwarzanie warunków do funkcjonowania organów władzy państwowej oraz przedstawicielstw dyplomatycznych; b) stwarzanie warunków do organizacji wydarzeń ogólnokrajowych i międzynarodowych; c) świadczenie usług komunalnych, transportowych, medycznych i innych organom władzy oraz przedstawicielstwom dyplomatycznym (art. 8 u.M.). Do obowiązków miejskiej rady deputowanych Mińska należy: a) zatwierdzanie statutu Mińska; b) zatwierdzanie budżetu i zasad urządzania miasta; c) realizacja innych pełnomocnictw (art. 10 u.M.). Rada deputowanych zatwierdza swoją wewnętrzną strukturę oraz podział miasta na jednomandatowe okręgi wyborcze. Obecnie liczy ona 57 deputowanych, którzy byli wybrani w $2018 \mathrm{r}$.

$\mathrm{Na}$ miejskim komitecie wykonawczym spoczywa obowiązek zapewnienia nieruchomości niezbędnych dla funkcjonowania organów władzy oraz przedstawicielstw dyplomatycznych, prowadzenie polityki zagospodarowania przestrzennego, opracowywanie wspólnie z Ministerstwem Architektury i przedstawianie rządowi propozycji Planu generalnego miasta Mińska, który zatwierdza prezydent Białorusi, reprezentowanie Mińska w stosunkach zewnętrznych oraz realizacja innych delegowanych mu pełnomocnictw (art. 9 u.M.).

Do obowiązków przewodniczącego miejskiego komitetu wykonawczego należy: a) zapewnienie organizacji przedsięwzięć o charakterze ogólnokrajowym i międzynarodowym; b) uczestnictwo w podejmowaniu decyzji o lokalizacji organów władzy i placówek dyplomatycznych oraz kwestii właścicielskich dotyczących tychże nieruchomości (art. 11 u.M.).

Ustawa ramowo określa zasady współpracy Rady Ministrów z mińskimi organami legislatywy i egzekutywy w zakresie realizacji funkcji stołecznych. Współpraca ta ma dotyczyć realizacji przedsięwzięć o charakterze ogólnokrajowym i lokalnym, opracowywania Planu generalnego miasta Mińska, kwestii transportowych oraz organizowania rynku zbytu dla krajowej produkcji rolnej i przemysłowej (art. 12 u.M.).

Pozycja ustrojowa organów władzy lokalnej została unormowana statutem Mińska z dnia 26 czerwca $2001 \mathrm{r}$. Liczy on 34 artykuły pogrupowane w 5 rozdziałów. Zgodnie z obowiązującym modelem samorządu lokalnego wyróżnia się organy zarządzania oraz organy samorządu. Do pierwszych $\mathrm{z}$ nich należy miejski komitet wykonawczy oraz administracje dzielnicowe. Do drugich - miejska rada deputowanych oraz terytorialne organy samorządu społecznego ${ }^{28}$ (art. 3 st.M.). Mińsk podzielony jest na dzielnice, zaś

28 Szerzej: R. Czachor, Terytorialne organy samorządu społecznego jako szczególna instytucja demokracji lokalnej w Republice Białoruś [w:] Aktualne wyzwania demokracji partycypacyjnej w Polsce i na świecie, P. Kuczma (red.), Polkowice 2017, s. 237-246. 
podziału tego dokonuje prezydent Białorusi na wniosek rządu, który działa na podstawie postulatu miejskiej rady deputowanych i miejskiego komitetu wykonawczego (art. 8 st.M.).

Rada miejska jest określona jako „przedstawicielski organ władzy państwowej i podstawowe ogniwo miejskiego systemu samorządowego" (art. 10 st.M.). Deputowani wybierani są bezpośrednio w wyborach powszechnych, równych i tajnych na czteroletnią kadencję (art. 10 st.M.). W zakresie kompetencji rady miejskiej Mińska znajduje się m.in.: a) zatwierdzanie planów i programów rozwoju społeczno-gospodarczego Mińska; b) zatwierdzanie i zmiana statutu Mińska; c) zatwierdzanie budżetu miasta i przyjmowanie sprawozdania z jego realizacji; d) zatwierdzanie wysokości miejscowych podatków i opłat (art. 11 st.M.). Katalog ten rozszerza treści zawarte $\mathrm{w} \mathrm{V}$ rozdziale konstytucji oraz art. 10 u.M. Przewodniczący rady jest wybierany na jej posiedzeniu spośród deputowanych w głosowaniu tajnym. Przewodniczący rady reprezentuje ją w stosunkach $z$ innymi organami władzy publicznej oraz $\mathrm{w}$ stosunkach międzynarodowych (art. 14 st.M.) Na jego wniosek spośród deputowanych wybierany jest zastępca przewodniczącego rady. Na prezydium rady spoczywa obowiązek przygotowania posiedzeń (art. 13 st.M.).

Miejski komitet wykonawczy jest „organem wykonawczym i zarządzającym na terenie Mińska" (art. 21 st.M.) i posiada osobowość prawną. Wprowadzono zasadę podwójnej odpowiedzialności komitetu: w kwestiach będących w zakresie kompetencji rządu odpowiada i podlega prezydentowi Białorusi i Radzie Ministrów, zaś w zakresie kompetencji miejskiej rady deputowanych - również przed nią. Tę drugą odpowiedzialność należy uznać za iluzoryczną, bowiem rada deputowanych nie posiada praktycznie wpływu na funkcjonowanie organu egzekutywy. Jako podstawowe zadanie miejskiego komitetu wykonawczego sformułowano „zapewnienie gospodarczego, społecznego i kulturowego rozwoju miasta, poprawę stanu środowiska naturalnego miasta oraz wykonywanie, $\mathrm{z}$ uwzględnieniem interesów ogólnopaństwowych, jako stolicy, jak i interesów mieszkańców, decyzji znajdujących się wyżej w hierarchii organów władzy państwowej" (art. 21 st.M.). W szczególności do kompetencji komitetu wykonawczego zaliczono: a) opracowanie strategii zrównoważonego rozwoju; b) przedstawienie radzie deputowanych projektu budżetu;c) dysponowanie majątkiem komunalnym; d) opracowywanie miejscowych planów zagospodarowania przestrzennego; e) prowadzenie polityki publicznej w zakresie: ochrony zdrowia, edukacji, pomocy społecznej, w sferze kultury, transportu, handlu, obsługi bytowej mieszkańców (art. 21 st.M.).

Przewodniczący miejskiego komitetu wykonawczego jest „najwyższym urzędnikiem państwowym i szefem egzekutywy na terenie Mińska" (art. 26 st.M.). Kandydat na przewodniczącego przedstawiany jest przez prezydenta Białorusi i zatwierdzany przez miejską radę deputowanych. Do 
jego kompetencji należy w szczególności: a) przedstawianie prezydentowi Białorusi i Radzie Ministrów propozycji aktów normatywnych dotyczących interesów miasta; b) uczestnictwo w posiedzeniach rządu w kwestiach dotyczących Mińska;c) współuczestnictwo w podejmowaniu decyzji o organizacji w Mińsku wydarzeń ogólnokrajowych i międzynarodowych; d) współuczestnictwo w podejmowaniu decyzji o lokalizacji organów władzy publicznej oraz przedstawicielstw dyplomatycznych (art. 26 st.M.). Pierwszego zastępcę oraz zastępców przewodniczącego komitetu wykonawczego powołuje przewodniczący komitetu za zgodę prezydenta Białorusi (art. 27 st.M.).

W dzielnicach Mińska nie funkcjonują organy uchwałodawcze, natomiast funkcje organów egzekutywy pełnią administracje dzielnicowe. Są zaliczane do struktur organów zarządzania, zatem nie są elementem samorządu lokalnego. Posiadają osobowość prawną. Na ich czele stoją szefowie administracji dzielnicowych, którzy powoływani są przez przewodniczącego miejskiego komitetu wykonawczego za zgodą prezydenta Białorusi (art. 32).

\section{Podstawy ustroju m.st. Kijowa}

Konstytucja Ukrainy stanowi, że Kijów jest jej stolicą (art. 19), której szczególny status jako miasta wydzielonego reguluje ustawa (podobny status posiada Sewastopol; art. 133). Wiąże się z tym norma konstytucyjna wprowadzająca szczególny charakter samorządu lokalnego w obu miastach (art. 140).

Ustawa o stolicy Ukrainy - mieście-bohaterze Kijowie z dnia 15 stycznia 1999 r. liczy 25 artykułów pogrupowanych w 7 rozdziałów. Stanowi ona, że Kijów jako stolica Ukrainy jest: a) politycznym i administracyjnym centrum państwa; b) siedzibą prezydenta, Rady Najwyższej, Gabinetu Ministrów, Sądu Konstytucyjnego i innych organów władzy centralnej (art. 1 ust 2. u.K.). Stołeczny status nakłada na lokalne organy władzy dodatkowe obowiązki władzy centralnej rządu i gwarantuje dodatkowe prawa (art. 1 ust. 5 u.K.). W szczególności gwarantuje się obowiązkowe finansowanie wydatków związanych z realizacją funkcji stołecznych przez budżet państwa (art. 19 u.K.).

Jednostkami administracyjno-terytorialnymi Kijowa są dzielnice, ich powołanie leży w gestii rady miejskiej, zaś granice miasta określa Rada Najwyższa na wniosek rady miejskiej (art. 2 u.K.).

W ramach realizacji funkcji stołecznych ustawa nakłada na lokalne organy władzy przede wszystkim następujące funkcje: a) tworzenie warunków do funkcjonowania organów władzy i przedstawicielstw dyplomatycznych; b) świadczenie im usług publicznych; c) współpraca w zakresie dotyczącym 
stolicy z prezydentem Ukrainy, parlamentem i rządem; d) ochrona dziedzictwa historycznego i kulturowego (art. 4 u.K.).

Ustawa stanowi, że system samorządu lokalnego w Kijowie tworzy: a) wspólnota lokalna; b) burmistrz (ukr. horodśkoj hołowa); c) rada miejska (funkcjonująca w oparciu o ustawę o samorządzie lokalnym na Ukrainie); d) organ wykonawczy rady miejskiej; e) rady dzielnicowe (o ile zostały powołane) (art. 7 u.K.).

Rada miejska może tworzyć dzielnice i w tym wypadku funkcjonują w nich dzielnicowe administracje państwowe, które podlegają miejskiej administracji państwowej, zaś w przypadku powołania rad dzielnicowych (co nie jest automatycznie implikowane przez fakt powołania dzielnic) również tym radom (art. 11 u.K.).

Prezydium rady miejskiej, będące organem konsultacyjnym, stanowi burmistrz, jego zastępca, przewodniczący stałych komisji rady oraz pełnomocnicy grup deputowanych (art. 12 u.K.).

Specyfiką samorządu kijowskiego pozostaje swoisty dualizm egzekutywy w postaci przewodniczącego kijowskiej miejskiej administracji państwowej oraz burmistrza. Zgodnie z ustawą o stolicy Ukrainy organem wykonawczym samorządu lokalnego jest kijowska miejska administracja państwowa, która realizuje funkcje samorządowe oraz rządowe. Jej przewodniczącego powołuje prezydent $\mathrm{w}$ trybie określonym $\mathrm{w}$ konstytucji (art. 10 u.K.). Przewodniczący kijowskiej administracji państwowej funkcjonował $\mathrm{w}$ oparciu o przepisy ustawy o przedstawicielu prezydenta Ukrainy $^{29} \mathrm{z}$ dnia 5 marca 1992 r., która w każdym obwodzie i mieście wydzielonym wprowadzała taki organ jako część tzw. pionu prezydenckiego, zaś od 1997 r. działa on na podstawie przywoływanej wcześniej ustawy o samorządzie lokalnym Ukrainy.

Z kolei stricte samorządowym organem egzekutywy jest pochodzący z wyborów bezpośrednich burmistrz. Jego zastępca z mocy prawa jest sekretarzem kijowskiej rady miejskiej (art. 13 u.K.). Do prerogatyw burmistrza należy m.in.: a) udział w przygotowaniu ustaw i innych aktów prawnych dotyczących Kijowa; b) udział w przygotowaniu wydarzeń o charakterze ogólnokrajowym i międzynarodowym; c) głos doradczy na posiedzeniach rządu dotyczących Kijowa; d) prawo przedkładania prezydentowi i rządowi Ukrainy projektów aktów prawnych dotyczących Kijowa. Na mocy orzeczenia Sądu Konstytucyjnego Ukrainy z dnia 25 grudnia 2003 r. ${ }^{30}$ prezydent

29 Закон України Про Представника Президента України, https://zakon.rada. gov.ua/laws/show/2167-12 (dostęp: 4.05.2019).

30 Рішення Конституційного Суду від 25 грудня 2003 року № 21-рп/2003 У справі за конституційним поданням Президента та 56 народних народних депутатів України про офіційне тлумачення положень частин першої, другої, третьої, четвертої статті 118, частини третьої статті 133, частин першої, другої, третьої статті 140, частини другої статті 141 Конституції України, статті 23, пункту 3 частини першої статті 30 Закону України „Про державну службу”, ста- 
został zobligowany do wyznaczania na przewodniczącego administracji państwowej osoby wybranej na burmistrza. Obowiązek ten zniosła nowelizacja ustawy o stolicy Ukrainy z dnia 7 września $2010 \mathrm{r}^{31}{ }^{31} \mathrm{~W}$ praktyce od czerwca 2014 r. oba urzędy pełni Witalij Kliczko.

Statut wspólnoty terytorialnej Kijowa liczy 38 artykułów w 5 rozdziałach. Jak unaocznia to tytuł dokumentu, jest to statut wspólnoty terytorialnej jako podmiotu samorządu lokalnego, który zawiera stypulacje odnoszące się do ustroju Kijowa. Określa on symbolikę miasta, święta miejskie, wprowadza tytuł obywatela honorowego oraz zasady bezpośredniej i pośredniej realizacji samorządności (art. 4-7 st.K.). W zakresie funkcjonowania organów uchwałodawczych i wykonawczych odsyła do regulacji ustawowych. W kwestii wyboru deputowanych rady statut także zawiera odesłanie do ustawy (art. 15-18 st.K.).

\section{Podstawy ustroju m.st. Kiszyniowa}

Konstytucja Mołdawii stanowi, że Kiszyniów jest jej stolicą (art. 14), której status reguluje ustawa organiczna (art. 110 ust. 3). Faktycznie zagadnienie ustroju stolicy Mołdawii szczegółowo uregulowane zostało w dwóch ustawach. Ustawa o municypalitecie Kiszyniów z dnia 17 lipca 2016 r. składa się z 30 artykułów w 7 rozdziałach. Stanowi ona, że mołdawska stolica posiada status jednostki administracyjno-terytorialnej drugiego szczebla, w skład której wchodzą gminy. Szczegółowe regulacje dotyczące tworzenia i funkcjonowania gmin w Mołdawii zawiera ustawa o podziale administracyjno-terytorialnym kraju z dnia 27 grudnia $2001 \mathrm{r}^{32}$

Zgodnie z ustawą z dnia 17 lipca 2016 r. organami władzy w municypalitecie Kiszyniowie są: rada municypalna, rady gminne, ponadto burmistrz generalny (rum. general primar) oraz burmistrzowie gmin (art. 3 u.m.K.). Rada municypalna i burmistrz generalny pełnią funkcję organów pierwszego szczebla dla Kiszyniowa.

Rada municypalna liczy 51 radnych, zaś tryb ich wyboru uregulowany został w Kodeksie wyborczym (art. 5 ust. 1 u.m.K.). W zakresie jej kompe-

тей 12, 79 Закону України „Про місцеве самоврядування в Україні”, статей 10, 13, 16 , пункту 2 розділу VII „Прикінцеві положення” Закону України „Про столицю України - місто-герой Київ”, статей 8, 10 Закону України „Про місцеві державні адміністрації, статті 18 Закону України „Про службу в органах місцевого самоврядування" (справа про особливості здійснення виконавчої влади та місцевого самоврядування у місті Києві), https://zakon2.rada.gov.ua/laws/show/v021p710-03 (dostęp: 4.05.2019).

31 Закон України Про внесення змін до Закону України „Про столицю України - місто-герой Київ” щодо порядку утворення районних рад, https://zakon2. rada.gov.ua/laws/show/2500-17 (4.05.2019).

32 Закон Республики Молдова № 764-XV от 27 декабря 2001 года Об административно-территориальном устройстве, http://lex.justice.md/ru/312874/ (dostęp: 4.05.2019). 
tencji leży podejmowanie wszystkich decyzji dotyczących Kiszyniowa, o ile nie są zastrzeżone dla innych organów władzy. Rada municypalna w szczególności: a) zatwierdza strukturę organizacyjną urzędu burmistrza generalnego; b) na wniosek burmistrza generalnego wyznacza jego zastępców; c) odpowiada za prowadzenie lokalnej polityki publicznej; d) zatwierdza strategię i plany rozwoju społeczno-gospodarczego oraz miejscowe plany zagospodarowania przestrzennego; e) zatwierdza proponowany przez burmistrza generalnego budżet, wyraża zgodę na zaciąganie pożyczek i kredytów (art. 6 ust. 2 u.m.K.).

Istotne, że rada municypalna nie posiada stałego przewodniczącego. Na każdym posiedzeniu rady wybierana jest osoba przewodnicząca obradom (art. 8 u.m.K.). Nad bieżącym funkcjonowaniem rady municypalnej i przygotowaniem jej posiedzeń czuwa wyłaniany w trybie konkursowym sekretarz rady. Do jego zadań należy także kontrasygnowanie uchwał rady (art. 12-13 u.m.K.). Kadencja rady może zostać skrócona w trybie przewidzianym w ustawie o lokalnym zarządzaniu publicznym (art. 13 ust. 3, art. 25,48 u.l.z.p.).

Monokratyczny organ egzekutywy - burmistrz generalny - jest określony jako organ wykonawczy reprezentujący wspólnotę municypalitetu i kierujący lokalną administracją publiczną (art. 14 u.m.K.). Wybierany jest on bezpośrednio, posiada prawo uczestnictwa $\mathrm{w}$ posiedzeniach rady municypalnej i zabierania głosu. Wśród zadań burmistrza generalnego znajduje się: a) realizacja uchwał rady municypalnej; b) prowadzenie polityki kadrowej; c) przygotowywanie budżetu oraz sprawozdania z jego realizacji; d) opracowywanie strategii i planów rozwoju; e) prowadzenie lokalnej polityki publicznej (art. 15 u.m.K.). Ustawa stanowi, że burmistrz generalny posiada 4 zastępców wybranych przez radę municypalną na wniosek burmistrza. Również na jego wniosek liczba zastępców może zostać zwiększona (art. 17 u.m.K.). Rada miejska posiada prawo zainicjowania odwołania burmistrza generalnego - wniosek musi poprzeć $2 / 3$ ogólnej liczby deputowanych (art. 10 ust. 5 u.m.K.).

Burmistrz generalny powołuje i odwołuje pretora, który zaliczany jest do wyższego korpusu urzędniczego. Pretor posiada swoich zastępców i kieruje urzędem pretury (art. 20 u.m.K.). Ustawa do zadań pretora zalicza: a) wykonywanie zadań z zakresu polityki publicznej oraz nadzorowanie funkcjonowania służb $\mathrm{w}$ tym zakresie; b) realizację poleceń burmistrza generalnego; c) realizację zadań z zakresu obrony cywilnej; d) zapewnienie poboru opłat i podatków (art. 22 u.m.K.).

Druga z przywoływanych ustaw, ustawa o lokalnym zarządzaniu publicznym z dnia 28 grudnia 2006 r., poświęca w całości rozdział 7 zarządzaniu publicznemu municypalitetem Kiszyniów. Wprowadza ona podział municypalitetu na sektory, miasto i wsie (art. 55 u.l.z.p.). Organami odpowiedzialnymi za zarządzanie publiczne są: burmistrz generalny muni- 
cypalitetu, rady i burmistrzowie (rum. primar) poszczególnych jednostek wchodzących w jego skład. Radni i burmistrzowie tych jednostek wybierani są $\mathrm{w}$ wyborach powszechnych. Ustawa nakłada na radę municypalną obowiązek koordynacji działań wszystkich pozostałych organów (art. 57 u.l.z.p.). Podobnie jak w przypadku municypalitetu jako całości, także w poszczególnych sektorach burmistrz generalny wyznacza swoich przedstawicieli w osobach pretorów (art. 59 u.l.z.p.).

\section{Wnioski końcowe}

Analiza podstaw ustroju stolic Białorusi, Ukrainy oraz Mołdawii wskazuje na określone różnice $\mathrm{w}$ tym zakresie. Są one ściśle związane z przyjętym modelem samorządu terytorialnego, co ma niebagatelny wpływ na zakres ich samodzielności.

Prawo Białorusi, definiując specyfikę jej stolicy, kładzie nacisk na sferę funkcjonalną i pełnienie roli siedziby instytucji państwowych i przedstawicielstw dyplomatycznych. Rada miejska Mińska posiada stosunkowo niewielki wpływ na funkcjonowanie burmistrza, który powoływany jest przez prezydenta państwa i wkomponowany jest strukturę scentralizowanej władzy wykonawczej w ramach tzw. pionu prezydenckiego. Postulowana reforma ustroju samorządu lokalnego Białorusi powinna przynieść wprowadzenie podległości organu egzekutywy miejscowym ciałom uchwałodawczym, a także decentralizację, w tym fiskalną.

Istota miasta stołecznego Kijowa jest zbieżna $\mathrm{z}$ podejściem białoruskim - wskazuje się na jego rolę w zakresie goszczenia na swoim terenie organów władzy i przedstawicielstw państw obcych. Trwająca reforma decentralizacyjna Ukrainy stwarza perspektywę wzmocnienia samorządów lokalnych. Obowiązujące obecnie rozwiązania są zasadniczo zgodne ze standardami państw europejskich. Za specyficzną sytuację należy uznać swoisty dualizm egzekutywy na poziomie stolicy - funkcjonowanie instytucji przewodniczącego kijowskiej miejskiej administracji państwowej oraz burmistrza. Likwidacja tej sytuacji i zapewnienie pełnej samorządności ukraińskiej stolicy powinno być zrealizowane m.in. w celu zapewnienia realizacji normy stanowiącej, że wspólnoty lokalne z mocy prawa dysponują samorządnością.

Status Kiszyniowa $\mathrm{z}$ kolei nie różni się w sensie funkcjonalnym od statusu innych jednostek administracyjno-terytorialnych drugiego szczebla. Za specyfikę utrudniającą $\mathrm{w}$ określonym stopniu funkcjonowanie miasta uznać można podział municypalitetu na mniejsze jednostki, co skutkuje ich nadmiernym rozdrobnieniem i instytucjonalną słabością. Także na poziomie municypalitetu struktura organów władzy wykonawczej jest zbyt rozbudowana (szczególnie w kontekście funkcjonowania pretora kierującego urzędem pretorii) i niewłaściwie dopasowana względem potrzeb. 
Podobnie jak w przypadku Białorusi i Ukrainy samorząd lokalny Mołdawii wymaga stopniowej optymalizacji struktury i wzmacniania jego kompetencji i samodzielności finansowej.

\section{Bibliografia}

Czachor R., Reformy ustroju samorzadu terytorialnego Ukrainy od 1990 do 2016 roku, „Samorząd Terytorialny” 2018, nr 3 (327).

Czachor R., Terytorialne organy samorządu społecznego jako szczególna instytucja demokracji lokalnej w Republice Białoruś [w:] Aktualne wyzwania demokracji partycypacyjnej w Polsce i na świecie, P. Kuczma (red.), Polkowice 2017.

Czachor R., Transformacja systemu politycznego Białorusi w latach 1988-2001, Polkowice 2016.

Czachor R., Ustrój samorządu lokalnego w Republice Mołdawii. Ewolucja i stan obecny, „Środkowoeuropejskie Studia Polityczne” 2019, nr 1.

Konstytucja Republiki Mołdawii, Warszawa 2014.

Konstytucja Ukrainy, Warszawa 1999.

Lutrzykowski A., Samorzad terytorialny - element ładu ustrojowego w Unii Europejskiej, „Athenaeum. Political Science” 2006, nr 14-15.

Макухин А., Реформа административно-территориального деления и местного самоуправления в Республике Молдова: между институциональной теорией и политической практикой, „Eastern Review” 2017, t. 6.

Pietrzko B., Ustrój i organizacja samorządu lokalnego Moskwy [w:] Samorząd miejski. Zadania, instytucje, normy, S. Wróbel (red.), Poznań-Chorzów 2008.

\section{Akty prawne}

Europejska Karta Samorządu Terytorialnego, sporządzona w Strasburgu dnia 15 października 1985 r., Dz.U. z 1994 r. Nr 124, poz. 607 ze zm.

Закон Nr. 136 от 17.07.2016 о статуте муниципия Кишинэу, http://lex.justice. $\mathrm{md} / \mathrm{ru} / 366632 /$.

Закон Nr. 436 от 28.12.2006 о местном публичном управлении, http://lex. justice.md/document_rus.php?id=0D9577C4:27DF0CCC.

Закон Республики Молдова № 764-XV от 27 декабря 2001 года Об административно-территориальном устройстве, http://lex.justice.md/ru/312874/.

Закон Республики Беларусь от 4 января 2010 г. № 108-3 „О местном управлении и самоуправлении в Республике Беларусь”, http://www.pravo.by/main.as $\mathrm{px}$ ?guid $=3871 \& \mathrm{p} 0=\mathrm{H} 11000108 \& \mathrm{p} 2=\{\mathrm{NRPA}\}$.

Закон Республики Беларусь от 20 февраля 1991 г. №617-XII „О местном управлении и самоуправлении в Республике Беларусь", http://www.levonevski.net/ pravo/razdelb/text646/index.html.

Закон Республики Беларусь от 10.01.2000 №362-3 „О внесении изменений и дополнений в Закон Республики Беларусь „О местном управлении и самоуправлении в Республике Беларусь”, http://www.levonevski.net/pravo/ norm2009/num36/d36275.html. 
Закон Республики Беларусь от 12.07.2000 №410-3 „О статусе столицы Республики Беларусь - города Минска”, http://pravo.newsby.org/belarus/zakon1/ z343.htm.

Закон СССР от 09.04.1990 „Об общих началах местного самоуправления и местного хозяйства в СССР", http://zaki.ru/pagesnew.php?id=1687.

Закон України Про внесення змін до Закону України „Про столицю України - місто-герой Київ“ щодо порядку утворення районних рад, https:// zakon2.rada.gov.ua/laws/show/2500-17.

Закон України Про добровільне об’єднання територіальних громад, http:// zakon3.rada.gov.ua/laws/show/157-19.

Закон України Про засади державної регіональної політики, http://zakon3. rada.gov.ua/laws/show/156-19.

Закон України Про місцеве самоврядування в Україні, https://zakon.rada.gov. ua/laws/show/280/97-\%D0\%B2\%D1\%80.

Закон України Про місиеві вибори, http://zakon5.rada.gov.ua/laws/show/595viii.

Закон України Про Представника Президента України, https://zakon.rada.gov. ua/laws/show/2167-12.

Закон України Про столицю України - місто-герой Київ, https://zakon.rada. gov.ua/laws/show/401-14.

Закон України Про співробітництво територіальних громад, http://zakon3. rada.gov.ua/laws/show/1508-18.

Конституция Республики Беларусь, http://pravo.by/pravovaya-informatsiya/ normativnye-dokumenty/konstitutsiya-respubliki-belarus/.

Решение Минского городского совета депутатов от 26 июня 2001 г. № 193 „Об утверждении устава города Минска”, http://pravo.levonevsky.org/ bazaby/org384/basic/text0187.htm.

Рішення Конституційного Суду від 25 грудня 2003 року № 21-рп/2003 У справі за конституційним поданням Президента та 56 народних народних депутатів України про офіційне тлумачення положень частин першої, другої, третьої, четвертої статті 118, частини третьої статті 133, частин першої, другої, третьої статті 140, частини другої статті 141 Конституції України, статті 23, пункту 3 частини першої статті 30 Закону України „Про державну службу”, статей 12, 79 Закону України „Про місцеве самоврядування в Україні”, статей $10,13,16$, пункту 2 розділу VII „Прикінцеві положення" Закону України «Про столицю України - місто-герой Київ”, статей 8, 10 Закону України „Про місцеві державні адміністрації, статті 18 Закону України „Про службу в органах місцевого самоврядування” (справа про особливості здійснення виконавчої влади та місцевого самоврядування у місті Києві), https://zakon2.rada.gov.ua/laws/show/v021p710-03.

Статут територіальної громади міста Києва, https://kmr.gov.ua/uk/content/ statut-terytorialnoyi-gromady-mista-kyyeva.

Указ Президента Республики Беларусь от 11.01.2001, n 21 „Об утверждении Положения о помощнике Президента Республики Беларусь”, http://pravo. newsby.org/belarus/ukaz3/uk571.htm. 
Streszczenie

W artykule podjęto zagadnienie ustroju prawnego stolic państw Europy Wschodniej - Mińska, Kijowa i Kiszyniowa. W kolejnych częściach artykułu omówiono podstawy systemu samorządu lokalnego Białorusi, Ukrainy i Mołdawii, najważniejsze akty prawne dotyczące ich stolic oraz zaprezentowano główne wnioski. Wskazano na istotne różnice w ustroju poszczególnych miast oraz słabości. W przypadku Mińska jest to potrzeba wprowadzenia nowego systemu samorządowego w skali kraju, zaś w przypadku Kijowa i Kiszyniowa - optymalizacja i wzmocnienie samorządu miejskiego.

Słowa kluczowe: samorząd lokalny, decentralizacja, Białoruś, Ukraina, Mołdawia

The Legal Status of the Capital Cities of Eastern European Countries (Belarus, Ukraine and Moldova)

Abstract

The paper tackles the issue of the legal status of Minsk, Kyiv and Chisinau, i.e. the capital cities of some Eastern European countries. The consecutive chapters of this article present the general characteristics of local government in Belarus, Ukraine and Moldova, key legal acts regarding capitals and final conclusions. The paper acknowledges significant differences in the legal position between these cities and some main weaknesses. In the case of Minsk, it is a strong need for the country's new local government model while in the case of Kyiv and Chisinau it is the need to optimise and strengthen the city's local government.

Keywords: local government, decentralisation, Belarus, Ukraine, Moldova 